\title{
Internal Validation Guide of the Amp F_STR Identifiler PCR by Using QuantifilerTM Y Human Male DNA Quantification for Use Forensic Laboratories
}

\author{
Mohammed Mahdi AL-Zubaidi \\ Forensic DNA Center for Research and Training, Al- Nahrain University. \\ E-mail: molecular_fdna@yahoo.com.
}

\begin{abstract}
Fifty samples of buccal swabs were collected from male oral cavity, then genomic DNA was extracted from each sample by two methods, the manual organic phenol chloroform methods and prepfiler forensic extraction kit methods.

The concentration of genomic DNA extracted was measured by using Quantifiler ${ }^{\circledR}$ Duo Kit throughout detection the SRY (FAM ${ }^{\mathrm{TM}_{-}}$labeled probe), RPPH1(VIC®-labeled probe) and an Internal Positive Control-IPC (NED ${ }^{\text {TM}}$-labeled probe).

Results showed that the concentration of genomic DNA in buccal swab was ranged between 0.26 and $9.422 \mathrm{ng} / \mathrm{ul}$. these samples work with a serial dilution decimal, as well as PCR .Then introduced to the device 3130xl Genetic Analyzer 16-capillary array system, The results showed that the concentrations is preferable which is located between $25-50 \mathrm{pg}$, as this did not appear in the concentrations of any problems and the emergence of the peaks clearly Compared with the ALLELIC ladder and positive control, After the election concentrations were chosen Thresholds, Peak amplitude thresholds.
\end{abstract}

Keywords: DNA, STR, Quantitative PCR, Internal validation.

\section{Introduction}

The field of human identification has progressed significantly in last years with the development of highly discriminating PCRbased DNA typing systems. The use of STR loci and highly sensitive instrumentation based on fluorescence detection enables rapid genetic profiling from minute amounts of biological material. As such, STR DNA typing analysis has been extensively used in forensic casework to establish the presence of a perpetrator's DNA in crime scene evidence. Biological evidence recovered at crime scenes often consists of mixtures of bodily substances originating from more than one individual, so mixed STR profiles are frequently encountered in criminal investigations. Profile interpretation in such cases normally follows a systematic approach (1-2).

Three major characteristics of the STR DNA typing process can impact on mixture interpretation:

1. Stutter peaks, which are minor peaks typically one repeat unit length shorter than that of their parent nominal allele peak and generated through strand slippage during amplification (3).
2. Sporadic imbalances in allele peak height or peak area ratios at heterozygous loci can also impact on mixture interpretation. However, imbalances can be triggered by stochastic effects when amplifying too little DNA or degraded DNA, or by the inability to remove PCR inhibitors during DNA extraction. These allelic imbalances can complicate the interpretation of mixed profiles if allele peaks from one contributor cannot be reliably identified because of significant signal imbalances.

3. The unpredictability concerning the number of shared alleles between contributors can also reduce the ability to identify individual profiles in a mixture (3).

STRs in a single reaction became available in the late 1990s/ early 2000s (4-5). PCR allowed the generation of genetic information from minute amounts of DNA; multiplexing of primers allowed the generation of genetic data from multiple sites from the same aliquot of DNA thus reducing sample consumption; fluorescent primers assisted multiplexing and new automated typing systems; and the use of STRs improved the chances of profiling poor 
quality samples. As the desire for higher discrimination power between individuals arose, the number of loci targeted by a single multiplex increased and there are now a number of commercially available, wellvalidated kits, incorporating 15-16 highly variable STR loci (plus amelogenin), such as Power Plex ${ }^{\circledR}$ ESX and ESI systems (6) and Amp FlSTR® NGM (7). These new kits also include improvements in primer design, buffer composition and amplification conditions which improve the analysis of trace samples (6-7).

Quantitative PCR (qPCR) has displaced hybridization based methods for humanspecific DNA quantification in forensic applications. qPCR has reduced the rate of false-negative STR results due to lack of sensitivity and increased the objectivity of data interpretation by providing a numerical output rather than requiring a visual comparison of band intensities. However, some current qPCR methods do not allow simultaneous quantification of total human and male DNA or do not have a level of sensitivity that consistently exceeds that of subsequent STR assays. A number of quantification procedures have been developed and are traditionally used to provide human specific DNA quantification, such as hybridization techniques as for example such as Quantifiler® Human DNA Quantification Kit and Quantifiler ${ }^{\circledR}$ Y Human Male DNA Quantification Kit (Applied Biosystems, foster City, CA) and most recently Quantifiler® Duo DNA Quantification Kit (Applied Biosystems, foster City, CA), for simultaneous quantification of total human and human male DNA proved to be very useful not only for human DNA quantification, but also for detection of DNA degradation and inhibitor's $(8,9)$. These are generally considered time-consuming, labour intensive, not suitable for automation and also low sensitive for STR genotyping systems (2), Real Time PCR (q-PCR) methods based on Taqman probes were developed in a single multiplex reaction, allowing the use of an additional internal template control to detect PCR inhibitors and Multiplex typing systems must be optimized to the point where they meet certain performance standards.
There are several governing bodies that ensure that high typing and analysis standards are maintained. Among these is the International Society for Forensic Genetics (ISFG), the Scientific Working Group on DNA Analysis Methods (SWGDAM), and the European DNA Profiling Group (EDNAP). These organizations have proposed guidelines for the use and validation of multiplex PCR typing systems. Some common validation exercises include: (1) establishing that the typing system is sensitive and performs consistently using freshly prepared and stored DNA, (2) that identical results are obtained irrespective of the type of tissue from which DNA was extracted, (3) that the systems yield consistent results in several laboratories, and (4) that the system performs well when used to analyze samples similar to those encountered in forensic casework (10) Validation plays a vital role in the forensic community since there is a constant influx of new DNA technology being developed (11). There are two types of validation processes; i.e. a developmental validation and an internal validation.

Developmental validation is the more thorough of the two methods and it is used to determine the reliability and limitations of a novel method (12). This entails the determination of: accuracy, precision, reproducibility, species specificity sensitivity, stability, PCR parameters and simulated casework studies (12). SWGDAM has recommended a set of developmental validation guidelines which are available fromwww.cstl.nist.gov/strbase/validation/SW GDAM.

Internal validation the purpose of an internal validation is solely to demonstrate the ability of a laboratory to perform a previously developmentally validated procedure (12). Both developmental and internal validations determine whether the analytical procedure will be adequate for its intended use (11).

\section{Materials and Methods}

DNA Extraction and Quantitation Fifty samples of buccal swabs were collected from human oral cavity and two methods for DNA extraction were used to isolate DNA: organic phenol chloroform manual $(13,14)$ and 
prepfiler forensic extreaction kit (Applied Biosystems).The quantity of human DNA was determined by two methods the Quantifiler TM human DNA quantitation kit (Applied Biosystems) and nano drop Q3000 UV spectrophotometer. DNA in this samples used for sensitivity studies was prepared by serial dilutions using for sensitivity studies was prepared by serial dilutions using Table (1).

Table (1)

Concentration of DNA and serial dilution for ten sample.

\begin{tabular}{|c|c|c|c|c|c|c|c|c|c|c|c|}
\hline \multirow{3}{*}{$\begin{array}{c}\text { Number } \\
\text { of sample }\end{array}$} & \multirow{3}{*}{$\begin{array}{c}\begin{array}{c}\text { Concentration } \\
\text { of DNA ng/ul }\end{array} \\
4.774 \\
\end{array}$} & \multicolumn{10}{|c|}{ Serial Dilution } \\
\hline & & \multicolumn{2}{|c|}{$10 p g+D . W$} & \multicolumn{2}{|c|}{$25 p g+D . W$} & \multicolumn{2}{|c|}{$50 p g+D . W$} & \multicolumn{2}{|c|}{$75 p g+D . W$} & \multicolumn{2}{|c|}{ 100pg+D.W } \\
\hline & & 0.209 & 99.79 & 0.26 & 49.73 & 0.52 & 49.48 & 0.79 & 49.21 & 0.94 & 49.06 \\
\hline Sample 2 & 1.27 & 0.78 & 999.21 & 0.984 & 48.01 & 1.97 & 48.03 & 2.95 & 47.05 & 3.54 & 46.46 \\
\hline Sample 3 & 2.91 & 0.34 & 99.6 & 0.42 & 49.57 & 0.86 & 499.14 & 1.29 & 488.71 & 1.55 & 48.45 \\
\hline $\begin{array}{l}\text { Sample } 4 \\
\end{array}$ & 9.422 & 0.11 & 99.89 & 0.13 & 49.87 & 0.27 & 499.73 & 0.40 & 499.60 & 0.53 & 49.47 \\
\hline Sample 5 & 2.87 & 0.35 & 99.65 & 0.44 & 49.56 & 0.87 & 49.13 & 1.31 & 48.69 & 1.74 & 48.26 \\
\hline Sample 6 & 5.9 & 0.169 & 99.83 & 0.21 & 49.79 & 0.42 & 49.58 & 0.64 & 49.36 & 0.85 & 49.15 \\
\hline Sample 7 & 0.26 & 3.85 & 96.15 & 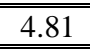 & 45.19 & 9.62 & 40.38 & 14.42 & 35.58 & 19.23 & 30.77 \\
\hline Sample 8 & 0.844 & 1.18 & 98.82 & 1.48 & 48.52 & 2.96 & 477.04 & 4.44 & 45.56 & 5.92 & 44.08 \\
\hline Sample 9 & 0.535 & 1.87 & 98.13 & 2.34 & 47.66 & 4.67 & 45.33 & 7.01 & 42.99 & 9.35 & 40.65 \\
\hline Sample 10 & 1.02 & 1.02 & 0.49 & 1.23 & 48.77 & 2.45 & 477.55 & 3.68 & 466.32 & 44.90 & 45.10 \\
\hline
\end{tabular}

\section{Real-Time PCR Amplification}

A multiplexed TaqMan ${ }^{\circledR}$ was assembled that amplifies SRY (FAM ${ }^{\text {TM}}-$ labeled probe), RPPH1 (VIC@-labeled probe) and an Internal Positive Control-IPC (NED ${ }^{\mathrm{TM}}$-labeled probe) (Table (2)). Assays were designed using the TaqMan ${ }^{\circledR}$ Gene Expression (16). Amplification reactions contained $2 \mathrm{ul}$ of sandards Dilution series (Std) starting concentration from $50 \mathrm{ng} / \mathrm{ul}$ (Std1) to $0.023 \mathrm{ng} / \mathrm{ul}$ or $23 \mathrm{pg} / \mathrm{ul}$ (Std8) sandards Dilution showed Table (3), Real-Time PCR reactions: Quantifiler duo primer mix, Quantifiler Duo pcr reaction Mix, Quantifiler Duo DNA standard and Quantifiler Duo Dilution Mix in the reaction use $10.5 \mathrm{ul}$ of Quantifiler Duo Primer Mix, $12.5 \mathrm{ul}$ of Quantifiler Duo Reactin Mix, and $2.0 \mathrm{ul}$ of DNA sample. Real-Time PCR program of cycler condition Table (4).

\section{Table (2)}

\section{Configuration of the Quantifiler ${ }^{\circledR}$ Duo Kit.}

\begin{tabular}{|c||c||c||c||}
\hline Target & Marker & Size & Dye \\
\hline \hline $\begin{array}{c}\text { Human } \\
\text { DNA }\end{array}$ & $\begin{array}{c}\text { RPPH1 } \\
\text { (Ribonuclease P } \\
\text { RNA component H1) }\end{array}$ & 140 bp & VIC $^{\circledR}$ \\
\hline \hline $\begin{array}{c}\text { Human } \\
\text { Male DNA }\end{array}$ & $\begin{array}{c}\text { SRY } \\
\text { (Sex determining } \\
\text { Region Y) }\end{array}$ & 130 bp & FAM $^{\mathrm{TM}}$ \\
\hline \hline IPC & Artificial Template & $130 \mathrm{bp}$ & $\mathrm{NED}^{\mathrm{TM}}$ \\
\hline
\end{tabular}


Table (3)

Preparation of DNA standards.

\begin{tabular}{|c|c|c|c|}
\hline Standard & $\begin{array}{c}\text { Concentration } \\
(\text { ng/ul })\end{array}$ & Minimum Amounts & Dilution factor \\
\hline Std1 & 50.000 & $\begin{array}{c}10 \mathrm{ul}(200 \mathrm{ng} / \mathrm{ul} \text { stock })+30 \mathrm{ul} \\
\text { Quantifiler Duo DNA dilution buffer }\end{array}$ & $4 \mathrm{X}$ \\
\hline Std2 & 16.700 & $\begin{array}{l}10 \text { ul(Std1)+20ul Quantifiler Duo } \\
\text { DNA dilution buffer }\end{array}$ & $3 X$ \\
\hline Std3 & 5.560 & $\begin{array}{l}10 \text { ul(Std2)+20ul Quantifiler Duo } \\
\text { DNA dilution buffer }\end{array}$ & $3 X$ \\
\hline Std4 & 1.850 & $\begin{array}{l}10 \text { ul(Std3)+ 20ul Quantifiler Duo } \\
\text { DNA dilution buffer }\end{array}$ & $3 X$ \\
\hline Std5 & 0.620 & $\begin{array}{l}10 \text { ul(Std4)+ 20ul Quantifiler Duo } \\
\text { DNA dilution buffer }\end{array}$ & $3 X$ \\
\hline Std6 & 0.210 & $\begin{array}{l}10 \text { ul(Std5)+ 20ul Quantifiler Duo } \\
\text { DNA dilution buffer }\end{array}$ & $3 \mathrm{X}$ \\
\hline Std7 & 0.068 & $\begin{array}{c}10 \text { ul(Std6)+ 20ul Quantifiler Duo } \\
\text { DNA dilution buffer }\end{array}$ & $3 X$ \\
\hline $\operatorname{Std} 8$ & 0.023 & $\begin{array}{l}10 \text { ul(Std7)+ 20ul Quantifiler Duo } \\
\text { DNA dilution buffer }\end{array}$ & $3 X$ \\
\hline
\end{tabular}

Table (4)

Real-Time PCR program.

\begin{tabular}{|c||c|c|}
\hline Temp & Time & Cycles \\
\hline \hline 50 & 2 mine & 1 \\
\hline \hline 95 & $10 \mathrm{mine}$ & 1 \\
\hline \hline 95 & $15 \mathrm{sec}$ & 40 \\
\hline \hline 60 & 1 mine & 40 \\
\hline
\end{tabular}

\section{Amplification for STRs}

Fifty autosomal STR markers (the 13 CODIS core loci and D19S433 and D2S1338) were typed along with amelogenin using the Applied Biosystems AmpFiSTR ${ }^{\circledR}$ Identifiler $^{\mathrm{TM}}$ kit (3) $1 \pm 2 \mathrm{ng}$ of target DNA following the protocols described in the User's Manual (applied Biosystems). The samples were amplifyed using verity PCR System (applyed Biosystems). The standard thermal cycling parameters were :1cycle $95^{\circ} \mathrm{C}$ for 11 minutes ; 28 cycle of $94{ }^{\circ} \mathrm{C}$ for 1 minuts , $59{ }^{\circ} \mathrm{C}$ for 1 minutes, $72{ }^{\circ} \mathrm{C}$ for 1 minutes and Final Extension $60^{\circ} \mathrm{C}$ for 60 minutes. (1ul) of PCR product. was mixed with $8.7 \mathrm{ul}$ of Hi-Di'TM Formamide and $0.3 \mu l$ of GeneScan TM 500 LIZ® size standard (Applied Biosystems). Separation and detection of PCR products were accomplished with ABI Prism ${ }^{\circledR}$ 3130xl Genetic Analyzer 16-capillary array system (Applied Biosystems) according to the manufacture's recommendation. Following data collection, samples were analyzed using Data Collection v. 2.0 software (Applied Biosystems, Foster City, CA, USA) and samples were analyzed by GeneMapper1 v. 3.2 software (Applied Biosystems, Foster City, CA, USA).

\section{Results and Discussion}

Fifty sample was measured using multiplex real-time PCR assay was assembled that amplifies sex determining region Y(SRY), ribonuclease P RNA component H1 (RPPH1) and a synthetic oligonucleotide sequence that served as an Internal Positive Control (IPC). Amplification reactions were performed on a 7500 fast Real-Time PCR System and the data were analyzed with the 7500 fast System SDS software v2.0.5 (Applied Biosystems, Foster City, CA). During real-time PCR, accumulation of the PCR product is monitored with each cycle. In the H-Quant assay, accumulated PCR product is measured by the fluorescence resulting from the binding of Human genomic DNA from donors was used to generate in a single reaction two standard curves for the human and the human malespecific targets with the DNA concentration 
ranging from $50 \mathrm{ng} / \mu \mathrm{l}$ to $23 \mathrm{pg} / \mu \mathrm{l}$ in three-fold increments. The eight concentration points are 50, 16.7, 5.56, 1.85, 0.62, 0.21, 0.068 and $0.023 \mathrm{ng} / \mu \mathrm{l}$ and $2.0 \mu \mathrm{l}$ of each sample were tested with the multiplex assay. IPC artificial template was included in each reaction to obtain the CT value of about 30 across the whole standard curve. The multiplexed assay performed well across a large dynamic range and is well suited for quantification of human samples. The standard curve plots and parameters are illustrated in Fig.(1), Fig.(2) and in Table (5). The detected $\mathrm{Ct}$ of approximately15 cycles for the lowest DNA concentration $(0.023 \mathrm{ng} / \mu \mathrm{l})$.

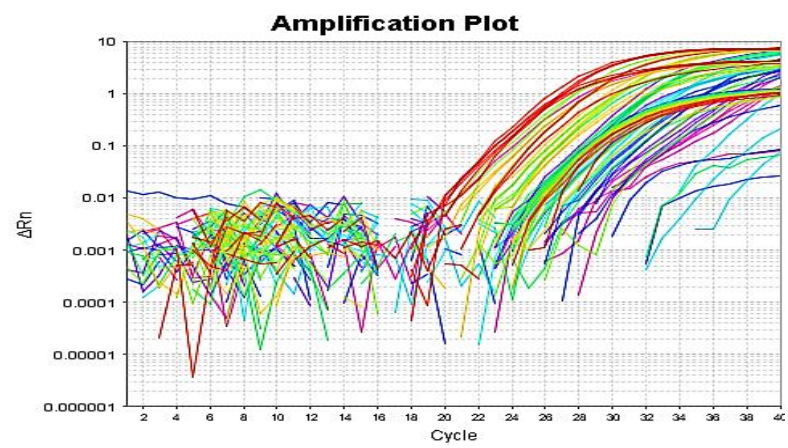

Fig.(1) :Amplification Plot - Standard DNA dilutions, controls and human sample.

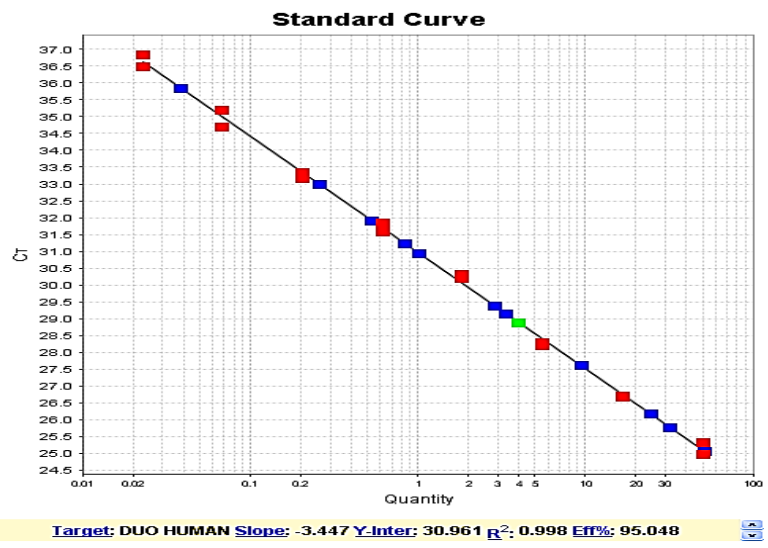

Fig.(2): Standard curves, IPC,CT values and samples for the Quantifiler ${ }^{\circledR}$ Duo Kit.

Table (5)

Standard curve parameters.

\begin{tabular}{|c||c|c|}
\hline & Value & $\begin{array}{c}\text { Typical Slope } \\
\text { (range) }\end{array}$ \\
\hline \hline R2 & 0.998 & $<98$ \\
\hline \hline Slope & -3.34 & $-3.0 \_-3.6$ \\
\hline \hline Efficiency & 95.045 & $90 \_105 \%$ \\
\hline Y-Intercept & 30.961 & 1 \\
\hline
\end{tabular}

Fifty sample were measured by Real Time PCR. These samples work with a serial dilution decimal, as well as work PCR Then introduced to the device 3130xl Genetic Analyzer 16-capillary array system, Knowledge for the purpose of concentrations the best that they appear peaks clearly and without artifacts.

Which will be based later in the laboratories Forensic DNA Center for Research and Training (FDNAC) in Al- Nahrain University. The results showed that the samples diluted samples with concentrations less than $25 \mathrm{pg}$ did not show their peaks clearly with the disappearance of some peaks than that the concentrations used are not good. The results of the samples with concentrations higher than 50pg appearance same artifacts such as stutter. high peaks and Unincorporated Dye. While concentrations is preferable which is located between 25-50, as this did not appear in the concentrations of any problems and the emergence of the peaks clearly Compared with the allelic ladder and positive control Fig. (3). These results focus adopted 25-50 pg in FDNAC labrotory Fig.(4). 



Fig.(3) :Allelic ladder, positive control, serial dilution of DNA and negative control.

\begin{tabular}{|c|c|c|c|c|c|c|}
\hline Min/Max Peak Height (LPHiMPH) & & & & & & \\
\hline Homozygous min peak height & 200.0 & Peak [ & etecti & & & \\
\hline Heterozygous min peak height & 100.0 & Peak & Amplitu & sholo & & \\
\hline Max Peak Height (MPH) & 5000.0 & B: & 200 & R: & 200 & \\
\hline Peak Height Ratio (FHR) & & G: & 200 & 0: & 200 & \\
\hline Min peak height ratio & 0.7 & 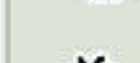 & & & & \\
\hline Broad Peak (EO) & & & & & & \\
\hline Max pesk with (basepairs) & 1.5 & Min. I & eak H & & 2 & pts \\
\hline Allele Number (AN) & & Polyn & omial D & & 3 & \\
\hline Max expected alleles & 2 & Peak & Windor & & 15 & pts \\
\hline & & &  & & & \\
\hline & & Peak & 5tart: & & 0.0 & \\
\hline & & & & & 0.0 & \\
\hline Cut-off value & 0.2 & & & & & \\
\hline
\end{tabular}

Fig.(4): Revaeals that ALL showing Thresholds, peak amplitude thresholds, Homozygous min peak height, Heterozygotes min peak height, Max peak height (MPH) and Peak height ratio (PHR). 


\section{Conclusions}

Quantification of human DNA in forensic samples is essential for defining input DNA needed for obtaining interpretable STR profiles. The most accurate method of choice for forensic DNA quantification is real-time PCR. We have developed a multiplex realtime PCR assay for the simultaneous quantification of human and human male DNA with IPC in forensic samples. The assay is efficient, specific, sensitive and robust. The results

Correlate well with the AmpF $\ell$ STR $₫$ Identifiler ${ }^{\circledR}$ and Yfiler ${ }^{\circledR}$ kit performance in terms of predicting the generation of interpretable STR profiles for inhibited DNA samples and male/female DNA mixtures. The Quantifiler ${ }^{\circledR}$ Duo DNA Quantification Kit is a useful tool for the quantitative and qualitative assessment of DNA in forensic type biological samples.

\section{References}

[1] Gill P., Sparkes R., Pinchin R., Clayton T., Whitaker $\mathrm{J}$ and Buckleton J. "Interpreting simple STR mixtures using allele peak areas", Forensic Sci Int, 91(41-53)., 1998.

[2] Evett IW., Gill PD., Lambert JA. "Taking account of peak areas when interpreting mixed DNA profiles", J Forensic Sci, 9,4362., 1998.

[3] Walsh PS., Fildes NJ., Reynolds R. "Sequence analysis and characterization of stutter products at the tetranucleotide repeat locus vWA", Nucl Acids Res, 2(14), $2807-$ 2812, 1996.

[4] Promega Corporation: GenePrint ${ }^{\mathrm{TM}}$ STR Systems Technical Manual, Part \#TMD004 Wisconsin: Promega, 1996.

[5] Holt CL., Buoncristiani M., Wallin JM., Nguyen T., Lazaruk KD., Walsh PS. TWGDAM validation of AmpFISTR PCR amplification kits for forensic DNA casework", J Forensic Sci, 47,66-96., 2002.

[6] Sprecher CJ., McLaren RS., Rabbach D., Krenke B., Ensenberger MG., Fulmer PM., Downey L., McCombs E., Storts DR. "Power Plex ESX and ESI systems: A suite of new STR systems designed to meet the changing needs of the DNAtyping community", Forensic Sci Int, Genet Suppl Series, 2,2-4., 2009.
[7] Applied Biosystems. Forensic News, NGM Kit; 2009 [http://marketing. appliedbiosystems.com/images/Product_Mi crosites/NGM/downloads/NextGen_SS_v2. pdf].

[8] Barbisin M., Fang R., O'Shea CE., Calandro LM., Furtado MR. "Developmental validation of the Quantifiler Duo DNA Quantification kit for simultaneous quantification of total human and human male DNA and detection of PCR inhibitors in biological samples", J Forensic Sci, 54,305-319, 2009.

[9] Barbisin M., Fang R., Furtado MR., Shewale JG. "Quantifiler ${ }^{\circledR}$ Duo DNA Quantification Kit: A Guiding Tool for Short Tandem Repeat Genotyping of Forensic Samples", Journal Forensic Research, 2,1-11., 2011.

[10] N. Leat., L. Ehrenreich., M. Benjeddou., S. Davison. "Developments in the use of Ychromosome markers in forensic genetics." African J. of Biotech, 12, 637642., 2004.

[11] J. M. Butler., C. S. Tomsey., M. C. Kline. "Can the validation process in forensic DNA typing be standardized? 15th International symposium on human identification", 2004.

[12] D. L. Daniels., A. M. Hall., J. Ballantyne. "SWGDAM developmental validation of a 19- locus Y-STR system for forensic casework", J. Forensic Sci. 49(4), 1-16., 2004.

[13] Sambrook J., Fritch E.F., Maniatis T. "Molecular Cloning: A Labora tory Manual. New York: Cold Spring Harbor Laboratory Press", 1989.

[14] Watson J. "Perkin-Elmer Corporation. Ampli Type User's Guide. Foster City: Version 2, DNA The secret of life. Random House Inc, New York, 2003.

[15] M. R. Furtado. "Real-Time Quantitative PCR in the Analysis of Gene Expression" Horizon Bioscience, Norfolk UK, 131-146, 2004. 


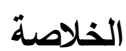

جمعت خمسين عينة من اشخاص اصحاء بواسطة

مسحة الفم اجري لها استخلاص بطريقتن الاولى هي هينه

التقليدية (فينول كلوروفورم) والطريقة الثانية هي استخدام عدة لبطن الثرين

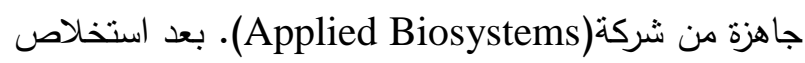



(QuantifilerTM human DNA quantitation kit) التي تتكون من ثلاث بروبات لغرض قياس تركيز DNA.

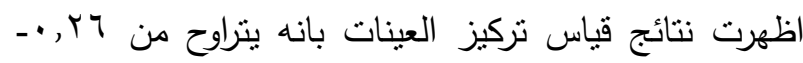

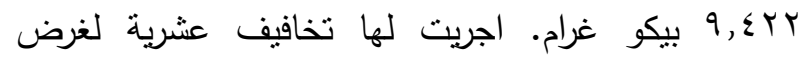
اختيار التركيز الامنل قبل ادخالها في جهاز الترحيل في انيل الانابيب الثعرية اظهرت النتائج ان افضل نركيز اعطى النى

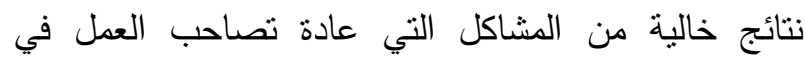
المجال الجنائي هو من هب-.0 من بكيوغرام مقارنة مع العينة القياسية. ثم بعدها اختيار خط العتبة الذب ظهرت عندة نتائج جيدة وكذلك اختيار ارتفاع العمود الامثل اذ يمكن اعنمادها في مجال عمل المختبرات الجنائية. 